\title{
Core-periphery relations in the Recuay hinterlands: economic interaction at Chinchawas, Peru
}

\author{
George F. Lau*
}

The author explores a changing core-periphery relationship in first millennium AD Peru, from the viewpoint of a small North Highlands village.

Keywords: first millennium AD, Peru, core-periphery, long-distance exchange, settlement studies, ceramics

\section{Introduction}

For many world regions, core-periphery perspectives have become increasingly important to model the interaction that ancient polities have with client or subject groups. These models benefit by focusing on regional asymmetries in political power and economics linking societies characterised by different levels of social organisation - as represented by the flow of goods, services and wealth from the periphery to the core (Algaze 1993; Chase-Dunn \& Hall 1991; Peregrine \& Feinman 1996; Rowlands 1987).

This paper examines the relationships between core polities and their hinterlands from the perspective of a small agro-pastoral village, Chinchawas, located in the North Highlands of Ancash, Peru (Figure 1). At different times during its principal occupation (AD 500-900), the community participated within larger political systems in different ways, as shown by a broad variety of evidence (i.e. ceramics, faunal remains and long-distance exchange).

I first describe Chinchawas in relation to a Recuay polity (AD 300-600), which was based in the Huaraz basin. The next two phases (together, AD 600-850) feature patterns attributed to the demise of Recuay and subsequent Wari expansion into the region, associated with the first pan-Andean polity (AD 700-900). This time was marked by strong economic growth, but general continuity in local cultural traditions. Late Wari influence at the site (AD 850-950) coincided with new patterns in ceramics and trading relations. Finally, the post-Wari period saw a significant decline in interaction and cultural elaboration, evidencing the collapse of previous economic and cultural networks. It is argued that the diachronic patterning of core-periphery interaction may be best reflected at a provincial level.

\section{Core-periphery perspectives and the ancient Andes}

Based on early Spanish sources, Rowe's classic survey (1946) outlined the uneven course of Inka conquest, in which it is implicit that a single model might not be able to account

* Sainsbury Research Unit, University of East Anglia, Norwich NR4 7TJ, UK (Email: george.lau@uea.ac.uk)

Received: 5 March 2004; Accepted: 13 April 2004; Revised: 18 April 2004

ANTIQUITY 79 (2005): 78-99 


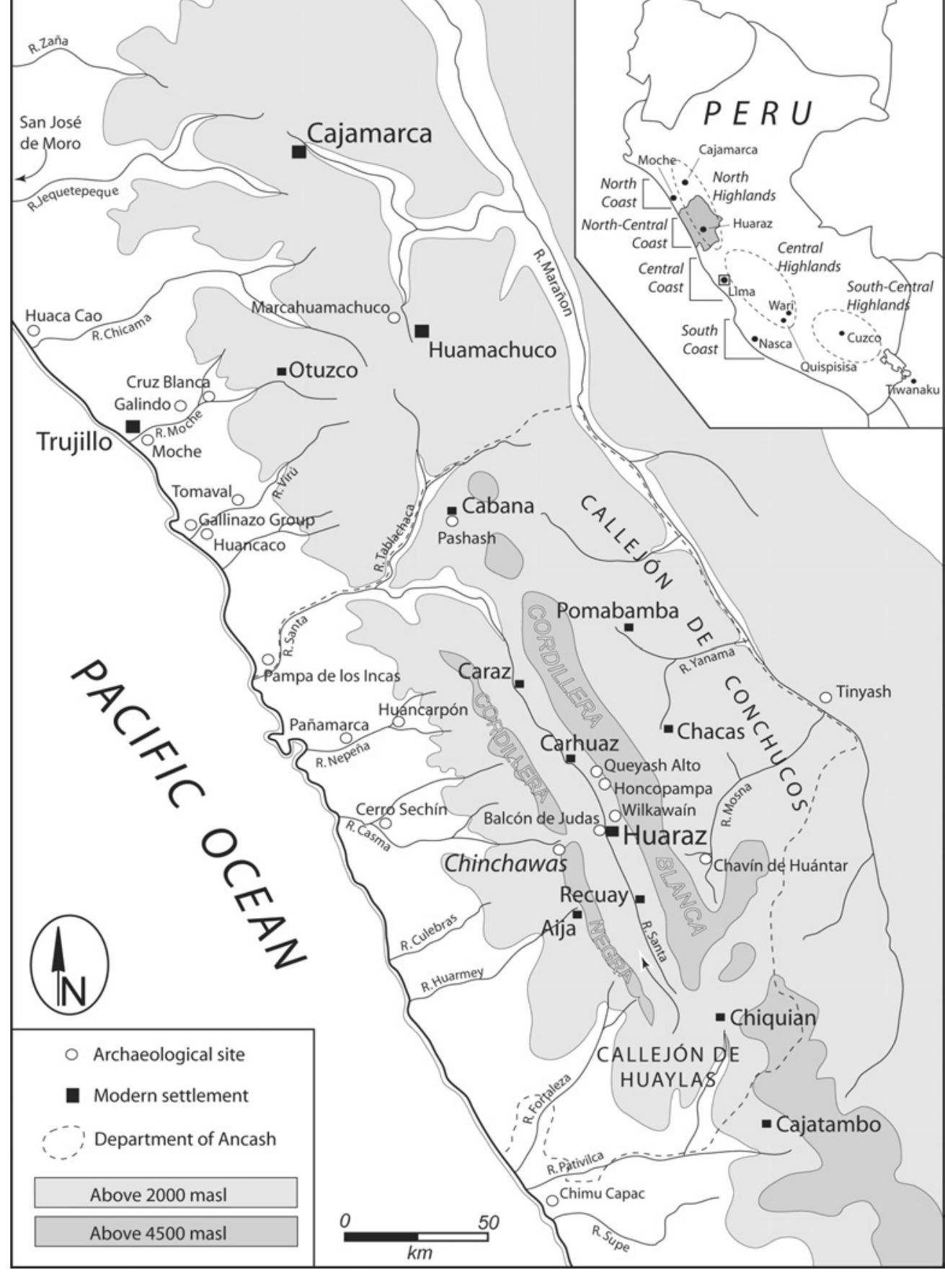

Figure 1. Map of northern Peru. Top right inset shows general archaeological regions of Peru and Ancash Department (after Lanning 1967; Lumbreras 1974). Overlooking a major coast-highland route into the rich intermontane valley of the Río Santa, the Callejón de Huaylas, Chinchawas maintained close cultural contacts with the groups in the Huaraz basin throughout antiquity, as reflected in traded ceramics as well as in shared cultural elements in local pottery, architecture and stone sculpture. Chinchawas later benefited from its strategic location through stronger interchanges with the coast. 
for the complexity of the empire's expansion and rule (D'Altroy 1992; Malpass 1993; Rostworowski 1988; Stanish 2001). Recent syntheses reiterate that archaic Andean polities were not monolithic political systems (D’Altroy 2002; Schreiber 1992; Stanish 2003). States establish different forms of relationships with provincial groups and adopt strategies to facilitate, or maximise, benefits for core groups. Different conditions warrant contextspecific solutions, such as coercion, taxation, redistribution, exchange and détente. Schreiber (1992) describes the Wari state as a geopolitical 'mosaic of control' featuring different methods and levels of provincial integration.

Recent studies engage explicitly with core-periphery perspectives and find different levels of applicability for the Andes (Burger \& Matos 2002; Goldstein 2000; Jennings \& Craig 2001; Kuznar 1996; La Lone 1994). Concerns about the comparability of the models arise, because mechanisms in Old World economics (e.g. markets, money and intensive transport (wheeled and seaborne), especially of staples), which are basic to Wallerstein's formulation (1974-80) of the capitalist 'World System', do not have clear analogues in the ancient Andes. Although the bureaucratic infrastructure, such as roads and storage systems, is well known for the Inka political economy (Hyslop 1984; Morris 1986), evidence for such phenomena and their temporal/functional interrelationships remain poorly known for earlier Andean systems (e.g. Burger 1992: 210; Schreiber 1991: 252; Topic 2003: 245). Scholars may also be reluctant to rely on any single model to characterise the uneven developments and diverse relationships that emerge in any given core and its periphery (McGuire 1996).

Different authors have recently stressed the need to study another dimension of complex social systems, specifically, the temporal correlates of expansion, and the archaeological variability expected through time (Kolata 2003; Kuznar 1996; Stanish 1997). Not only should polities maintain a range of relationships with peripheral groups, communities and regions, but we should also expect that these relationships will change, as polities mature, consolidate and weaken. Although a trajectory of change is fundamental to all complex societies, this process in the Andes is poorly detailed. The literature often lacks appropriate data from the periphery and tends to emphasise the presence/absence of foreign influences. Local patterns, rural agency and fine-grain diachronic variability continue to remain a low priority in current studies.

In part, the focus on the geographic extent of core polities is a natural outgrowth of a topdown approach that privileges the perspective from the core. This is because the economies of core areas come to rely upon the co-opting and extraction of resources from neighbouring groups and regions (e.g. Adams 1965; D’Altroy \& Earle 1985; Schwartz \& Falconer 1994). Spatial relations are also highlighted due to the increasing reliance on regional settlement survey and macro-scale analysis as primary research strategies (e.g. Jennings \& Craig 2001).

The economic interaction of core systems, however, can be usefully illuminated from a sitelevel, provincial perspective (e.g. Bermann 1994; Isbell 1977). Rural settlements often show considerable diversity and complexity in material culture, economic specialisation and socioeconomic arrangements (Goldstein 2000; Schwartz \& Falconer 1994). D’Altroy (2002: 8) concedes that, even for massive systems such as the Inka, ‘. . within local communities, it has become increasingly clear that many important activities... occurred without the intervention, interest, or awareness of the central authorities. Essentially, I follow arguments which emphasise that the relationships between core and periphery are shaped by a series of social and 
economic conditions which transform culture at the regional and local level. Rural case studies are invaluable for understanding ancient social complexity because they provide evidence for cultural variability within a core system and for the timing and nature of core/periphery interaction.

For archaeologists, the critical question remains: what material evidence can be used to discern core/periphery relationships? The artefact class par excellence has been ceramics. For the Central Andes, Menzel's stylistic analyses of ceramics $(1959,1964)$ laid the foundations for periodising state expansion. Menzel argued that different periods, or epochs, of political intervention became visually manifest through local cultures, especially in finely made ceramics. Recently, pottery evidence has been used, for the Chavín (Burger 1993; Burger \& Matos 2002; Druc 1998), Tiwanaku (Janusek 2002) and Inka (Bray 2003) cases, to model administrative practices away from the core, vis-à-vis different levels of local agency. Provincial groups and leaders, it is argued, are empowered through emulation, ethnic differentiation and feasting, respectively.

Administrative and religious architecture also comprise important correlates for core expansion in the Andes (e.g. Goldstein 1993; Hyslop 1990; Isbell \& McEwan 1991; Menzel 1959; Moore 1996). Menzel (1959: 140) asserted that in areas with strong existing centralisation, the Inka intervened in already established centres to rule through the native nobility... In the valleys in which there was no centralized authority already, the Incas imposed their own, constructing an administrative center at some convenient point to serve as the focus of Inca control'. Hinterland installations perform critical functions: defence, storage and military administration, residences, public ceremony, craft production and highly visible monuments of authority and annexation. Activities (e.g. redistribution, feasting) associated with state structures often facilitate and naturalise the exploitative interests of the dominant group (Bray 2003; Godelier 1977; Morris \& Thompson 1985).

In this paper, different types of evidence will be reviewed to track core-periphery relations through time. Specifically, data on ceramic exchange, obsidian and faunal resources will be employed to characterise five different periods of inter-regional interaction found locally at the site of Chinchawas.

\section{Previous research and field investigations at Chinchawas}

The hilltop settlement of Chinchawas lies in the western flanks of the Andes at $3850 \mathrm{~m}$ asl. The site benefits by its location near one of the lowest mountain passes of the Cordillera Negra and a strategic vantage above an important coast-highland route (still used today) between Casma on the coast and the Callejón de Huaylas, a key intermontane valley in northern Peru. The lands around Chinchawas, near the upper limits of agriculture, c. $3900-4000 \mathrm{~m}$ asl, continue to support high-altitude cultivation and pastoral strategies today.

Chinchawas measures about 4 ha in extent and features two major zones of well-preserved stone architecture (Figure 2). Sector 1 refers to the main ridge-top with a series of enclosures, walled terraces, room complexes and special-use constructions. To the east, Sector 2 consists entirely of small subterranean and aboveground mortuary constructions (chullpas). Test and horizontal excavations in 1996-97 determined that Sector 1 functioned mainly for 


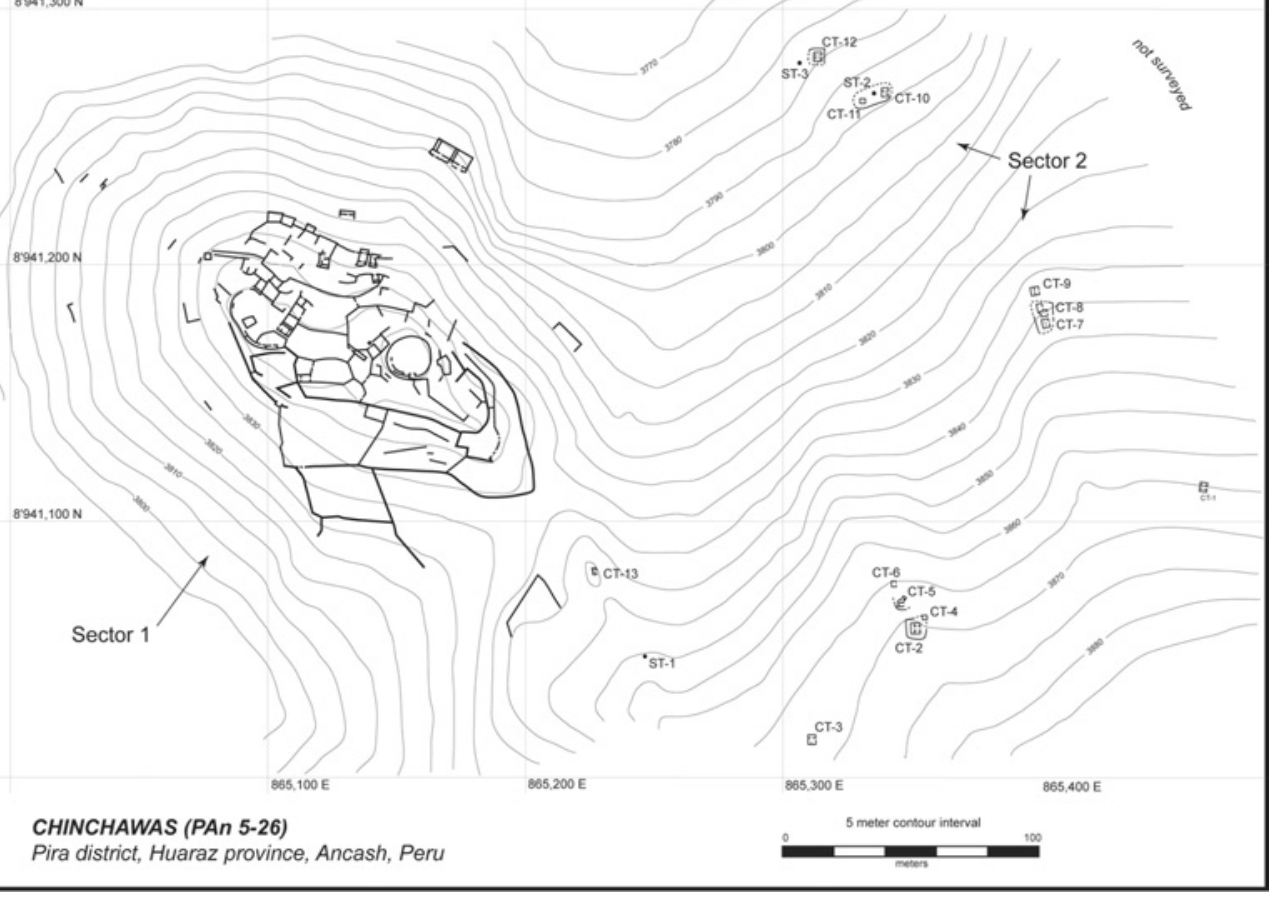

Figure 2. Map of the Chinchawas site. Sector 1 consists mainly of residential and public architecture on the principal hilltop, with large perimeter walls and corral areas. Sector 2 comprises a series of subterranean tomb structures (ST) and aboveground mortuary monuments, known as chullpas (CT).

residential and public activities, while Sector 2 served exclusively as a cemetery area. This paper focuses on general phase assemblages found across different functional contexts.

The groups who inhabited Chinchawas were largely rooted in the cultural tradition known as Recuay (Lau 2004). With its heartland in the Ancash highlands, Recuay culture (AD 250-600) is expressed principally through distinctive pottery, mortuary practices, architecture and stone sculpture (Bennett 1944; Grieder 1978; Ibarra 2003; Reichert 1977; Schaedel 1952; Tello 1929). The pottery features thin fabrics (sometimes of kaolinite), polychrome and negative (resist) painting, sculptural modelling and a distinctive series of vessel forms, iconographic motifs and themes. Recuay's central location in northern Peru facilitated stylistic and economic interchanges with contemporary neighbouring groups (e.g. Moche, Cajamarca, Gallinazo and Lima). Later, Recuay peoples were affected by developments attributed to Wari expansion (e.g. Lumbreras 1974; Schaedel 1993). Artistic imagery, including carved stone, fortified sites and evidence for weapons also indicate that warfare was a critical concern for Recuay groups.

Schaedel (1952: 143-76) first defined Recuay 'peripheral areas' and 'centres' (including Huaraz), based mainly on stylistic analyses of stone sculpture, and also inferences from pottery and site size associations. Now almost completely covered by a modern city, ancient Huaraz was the largest settlement in the Huaraz basin, if not the entire Callejón de Huaylas, during the Early Intermediate Period. It was certainly the largest site within a day's walking 
distance of Chinchawas in a settlement system that appears to be characterised by a site hierarchy - Huaraz as the primary centre, followed by a series of hilltop villages, smaller hamlets and cemeteries.

Scholars argue that the combination of monumental architecture (Pomakayán, Panteón), monolithic sculpture (Huallac, Panteón) and rich tombs and offerings (Jancu, Ichik Wilkawaín, Wilkawaín, Shankaiyan, Marian), all within the orbit of greater Huaraz, suggests different levels of social differentiation and access among communities comprising its 'core' or 'centre' (Schaedel 1952; Smith 1978: 33-4). Wegner (1988: 2) uses the terms 'cacicazgos o reinos pequeños' (small kingdoms or reigns) explicitly to describe socio-political arrangements in five major Recuay settlements in highland Ancash, including Huaraz. The term 'cacicazgos' is based on ethnohistoric documents and commonly refers to large ethnic groups headed by hereditary lords, strong social stratification and levels of authority over dispersed communities and resources.

Although not the only interpretation, the most plausible under the current evidence is of a Huaraz-based cacicazgo during the Early Intermediate Period and early Middle Horizon. In this working model, the following data descriptions indicate that Chinchawas groups maintained strongest ties with the Huaraz core during the early phases (Kayán and Chinchawasi 1). These relations later waned, probably fuelled by Wari expansion (Chinchawasi 2) and then by increased interaction with the coast (Warmi).

\section{Chronology}

The most fundamental observations on culture change derive from ceramic analysis. As the details are described elsewhere (Lau 2001: 177-334), only a precis is presented here. A five-phase sequence - based on local decorated and utilitarian ware groups - was developed for the site's occupation, overlapping principally with the Early Intermediate Period (AD 1-700) and the Middle Horizon, (AD 700-1000) (Lanning 1967; Rowe and Menzel 1967). Ten radiocarbon assays from Sector 1 help us to provide absolute age ranges for the phases (Lau 2004).

In general, the plainware ceramics by phase show continuity in form, fabric and surface treatment. Local decorated wares, meanwhile, exhibit the most innovative and stylistic borrowing. The earliest occupation of the site is associated with the Kayán style, a local variant of classic Recuay kaolinite pottery dating to the mid Early Intermediate Period. Chinchawasi 1 comprised a late Recuay style, which emulated Recuay stylistic features from the Huaraz area, and dates to the terminal Early Intermediate Period.

Innovations in form and painted decoration distinguish Chinchawasi 2 ceramics and reflect the disappearance of earlier Recuay elements and a concomitant surge of intrusive elements. Radiocarbon ages and trade pottery associations, including early Wari contemporary styles, indicate an early-to-mid Middle Horizon age. The final phase of intensive occupation, as represented by the Warmi style, witnessed the displacement of local pottery traditions by derived Wari styles. The Warmi style pertains to the mid-to-late Middle Horizon. The subsequent Chakwas phase began around the turn of the millennium and is characterised by rustic earthenwares adorned with simple plastic decoration. Intensive occupation of the Chinchawas hilltop ceased at this time. 


\section{Ceramic exchange}

Long-distance exchange provides the most sensitive data for identifying Chinchawas' external relations by phase. The sample consists of 786 fragments of fine/imported pottery acquired outside the immediate Chinchawas area (Table 1). Imported ceramics were recovered from stratigraphic deposits from all phases, except the Chakwas occupation.

\section{Kayán}

The Kayán occupation (AD 300-600) contained a small amount of fine ceramics $(n=$ 72). The sample consists predominantly of kaolinite ware in the Recuay tradition (Figure 3). Decorative treatments included a bright red slip and painted repeated lines and geometric motifs along the exterior rim of open bowls. Large quantities of this pottery were found at the site of Balcón de Judas, in Huaraz (Wegner 2003). No production centres are known at present, but the closest known kaolinite sources in Ancash are located in the Callejón de Huaylas, to the north of Huaraz (Topic 1985).

During the Kayán phase, Chinchawas showed other strong cultural links to an important Recuay centre based in the Huaraz area. In particular, Chinchawas peoples produced Recuay stone sculpture in the 'Huaraz peripheral area' style (Schaedel 1952: Map III). The sculptures, together with the kaolinite pottery, were used in distinctive funerary practices shared by Recuay groups (Lau 2002; Tello 1929). Overall, the current evidence indicates that the Kayán phase reflects a light occupation characterised by strong insularity in terms of cultural interaction, with little pretensions to wealth or status.

\section{Chinchawasi 1}

A wider range of external contacts prevailed during the Chinchawasi 1 occupation (c. AD 600-700) (Table 1). Of the sample $(n=63)$, pottery was acquired from the North Highlands (Recuay style: 19 per cent; indeterminate kaolinite: 25 per cent; fine pinkware: 4.8 per cent), the Central Highlands (Wari style: 3.2 per cent) and the North Coast (Late Moche style: 14 per cent). In addition, polished blackware (30 per cent), probably of North Highland and/or North Coast derivation, became important. Chinchawasi 1 peoples continued to acquire North Highland imports, especially Recuay. Central Highland materials appeared for the first time. There were also new coastal connections, such as Late Moche ceramics (Figure 4a, b). Local groups, therefore, were actively participating in exchange networks connecting the Central to North Highlands, and the North Coast.

The exotic wares suggest limited but selective trade relations with neighbouring regions with strong independent cultural traditions. By the end of the seventh century AD, powerful polities emerged in the Central Highlands (Isbell 1988; Schreiber 1992), the North Coast (Bawden 1996; Pillsbury 2001; Shimada 1994) and in Cajamarca and Huamachuco (Topic \& Topic 2000; Topic 1991). The growing presence of prestige goods from these regions, therefore, appears to have coincided with new geopolitical arrangements (Shady Solís 1988). Despite their autonomy, small communities such as Chinchawas may have been quite cognizant of regional developments and their exotic commodities. Among the prestige cultures, Wari-affiliated goods became increasingly important. 


\section{G.F. Lau}

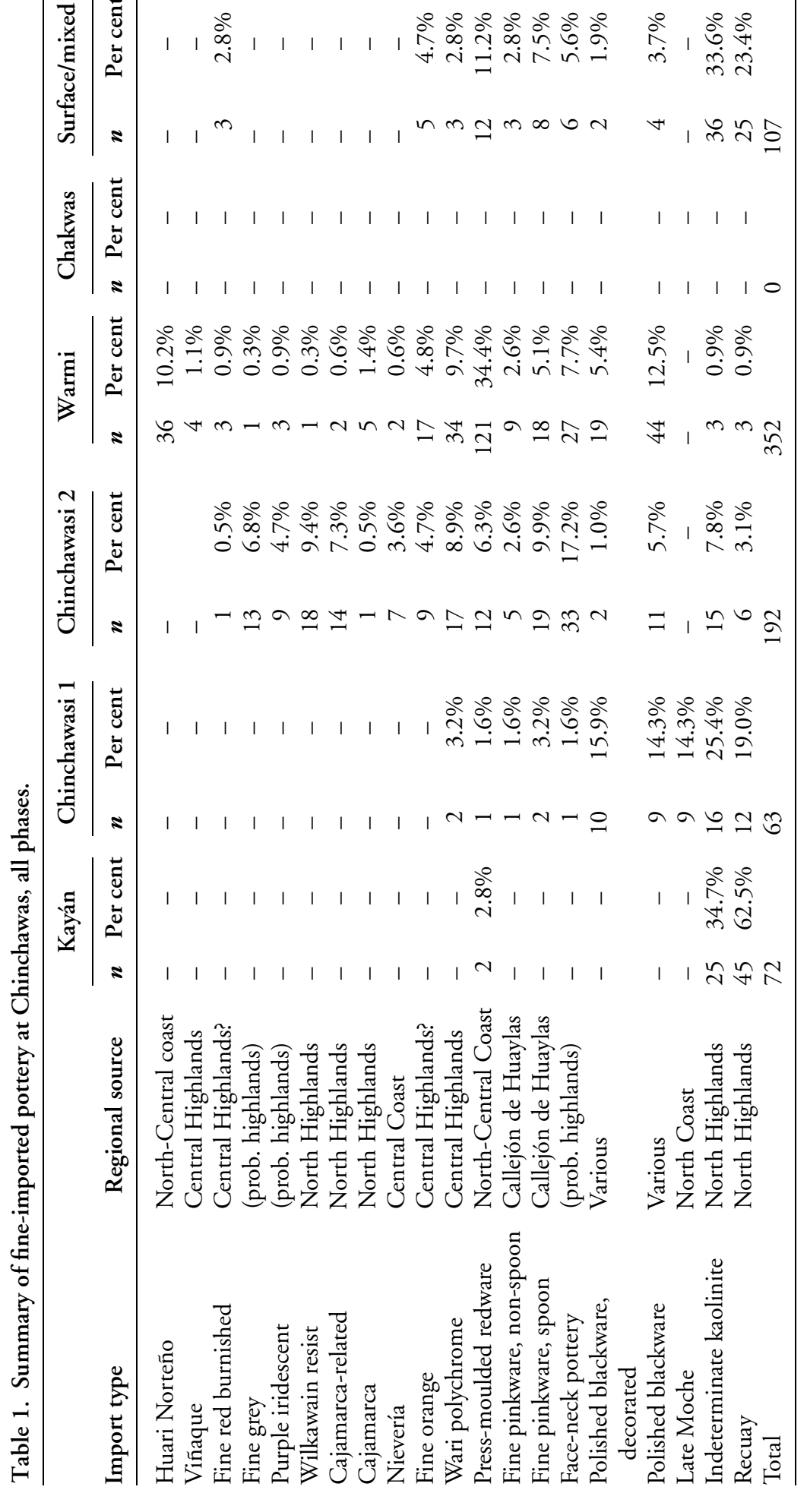




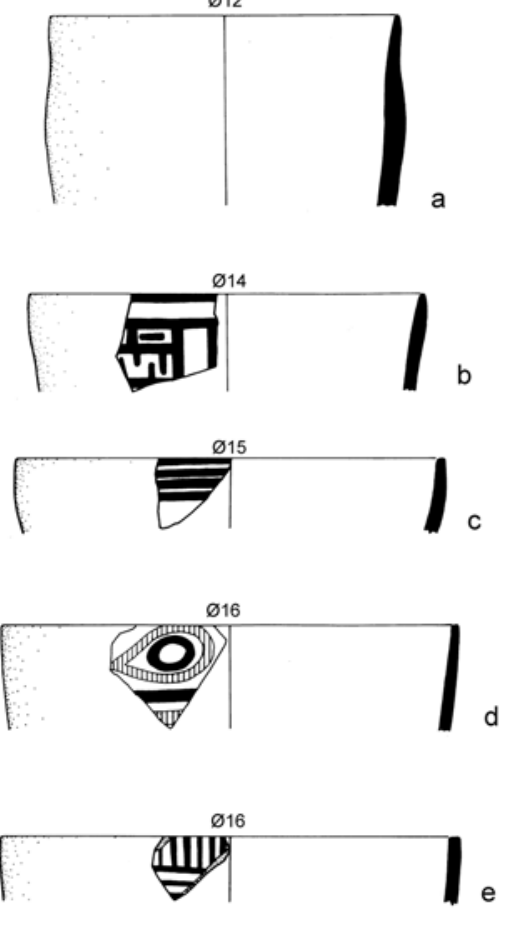

an
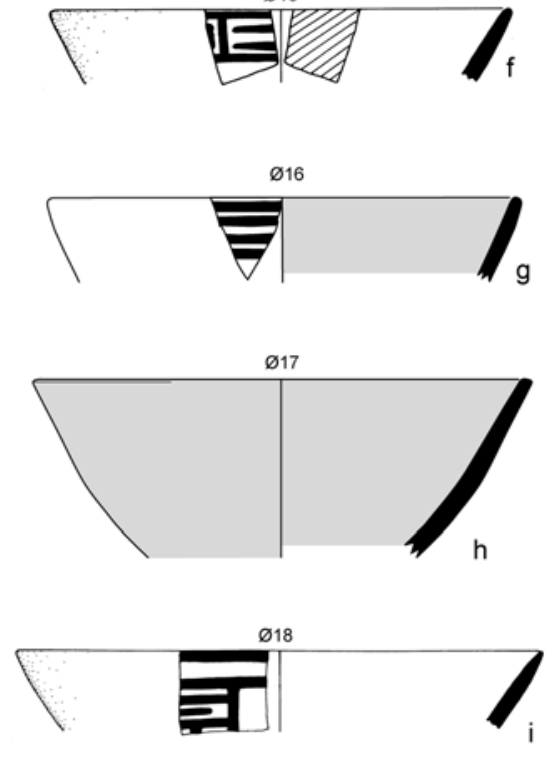

orange or red slip

dark brown or black

red

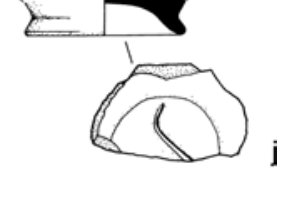

Figure 3. Recuay style pottery at Chinchawas, including straight-sided bowls (a-e), everted profile bowls (f-i) and a fragment of a ring base (j), with ' $S$ '-shaped makers mark. The pottery shows strong similarities to Recuay vessels from sites near Huaraz.

\section{Chinchawasi 2}

The importation of ceramics increased greatly during the Chinchawasi 2 phase (AD 700$850)$. A greater quantity $(n=192)$ and repertoire of foreign fine pottery demonstrate intensification of existing trade networks as well as a diversification of regional connections.

Chinchawasi 2 peoples continued to have strong connections to the nearby Callejón de Huaylas. Compared to Chinchawasi 1, fine pinkware, usually in the form of small polychrome spoons, increased sharply - from 3.8 per cent to 12.5 per cent of the respective phase totals. As expected, kaolinite vessels decreased in popularity.

New North Highland styles appeared for the first time. A continuing predilection for prestigious kaolinite wares is demonstrated by Cajamarca and Cajamarca-related styles (Figure 4c-f). The 'Wilkawaín resist' style (9.4 per cent), best known from several complete platters featuring ornate negative painting (Bennett 1944: Figure 8), appears to have had a limited distribution within the Callejón de Huaylas (Figure 4g).

Interaction with the Central Highlands was also pervasive, with Wari-related polychrome styles accounting for 8.9 per cent of the imported total. Wari influence is also manifested in fine orange and fine red burnished vessels. These bear close affinities to 'secular' wares 

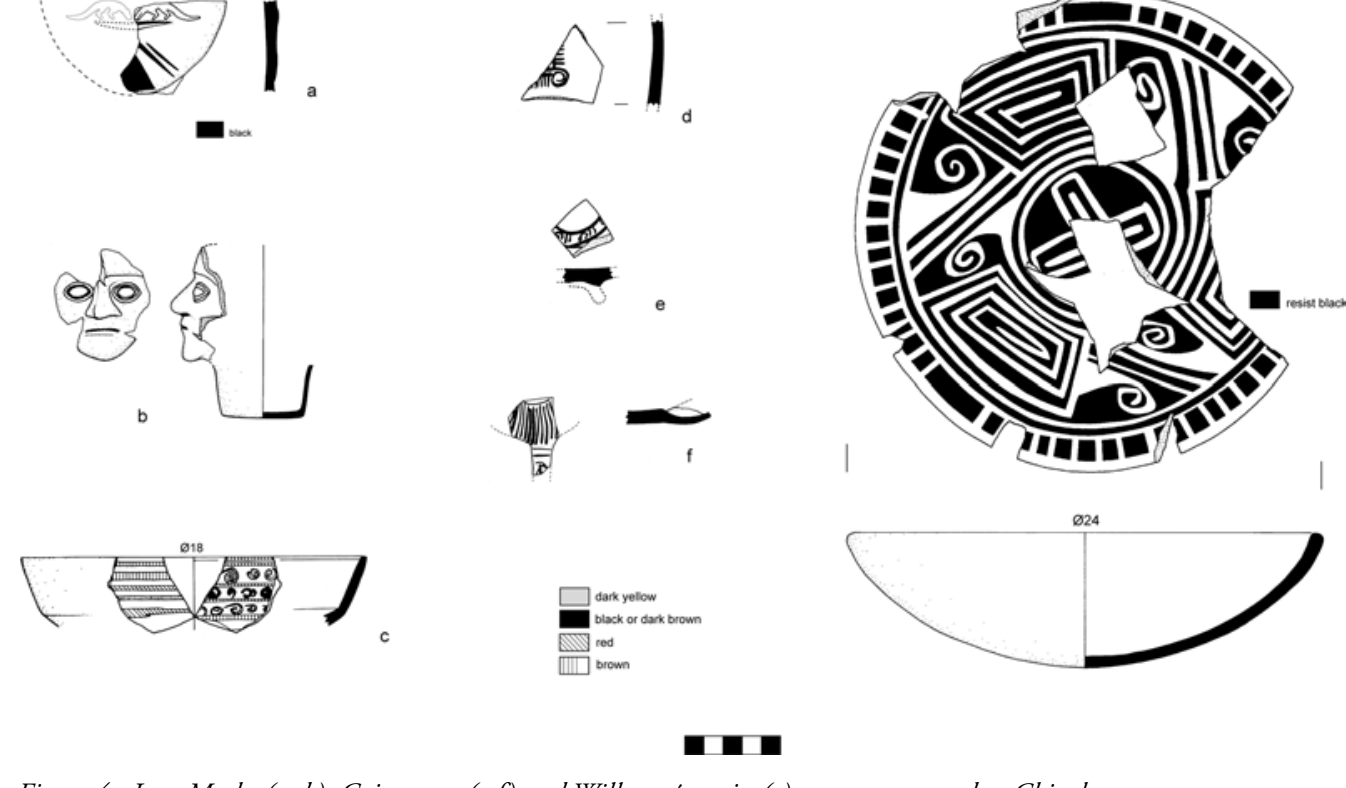

Figure 4. Late Moche (a, b), Cajamarca (c-f) and Wilkawain resist (g) pottery recovered at Chinchawas.

produced in the Central Highlands during the Middle Horizon (Anders 1989; González Carré et al. 1999; Isbell 1977; Lumbreras 1960; Menzel 1964).

Small amounts of Central Coast imports occurred in the form of Nievería style spouted/ effigy vessels (Figure 5a, b). In addition, press-moulded wares (6.3 per cent) typical of the North-Central to North Coast, especially the Virú and Supe valleys (Menzel 1977), are precursors to their popularity in later Warmi contexts.

Several styles can be categorised as foreign wares but cannot presently be identified to any source. Polished blackware (6.7 per cent), which show affinities to wares from the Callejón de Huaylas as well as the coast, decreased in popularity. Face-neck vessels, probably associated with new cultural dispositions propagated by Wari, increased sharply to 17 per cent of the phase total.

Several observations can be made regarding the Chinchawasi 2 imported pottery sample. First, there was more than a threefold increase in the total number of sherds compared to the previous phase. The greater frequency suggests that local peoples acquired and used imports on a wider basis. Second, the exchange network expanded to include the Cajamarca, North Central Coast and Central Coast regions. The unprovenanced fine wares suggest that other cultures and regions may have participated in the network. Thus, local peoples exploited existing long-distance exchange routes more intensively and cultivated new inter-regional ties.

Chinchawasi 2 peoples, apparently, became increasingly interested in the consumption of prestige goods. Chinchawas' emergence as a node in a far-ranging exchange network coincided with Wari expansion into the Callejón de Huaylas and other parts of Peru (Menzel 1964). The community, however, never appears to have been directly integrated by Wari. There are some stylistic affinities between Chinchawasi 2 and Wari styles, and there 

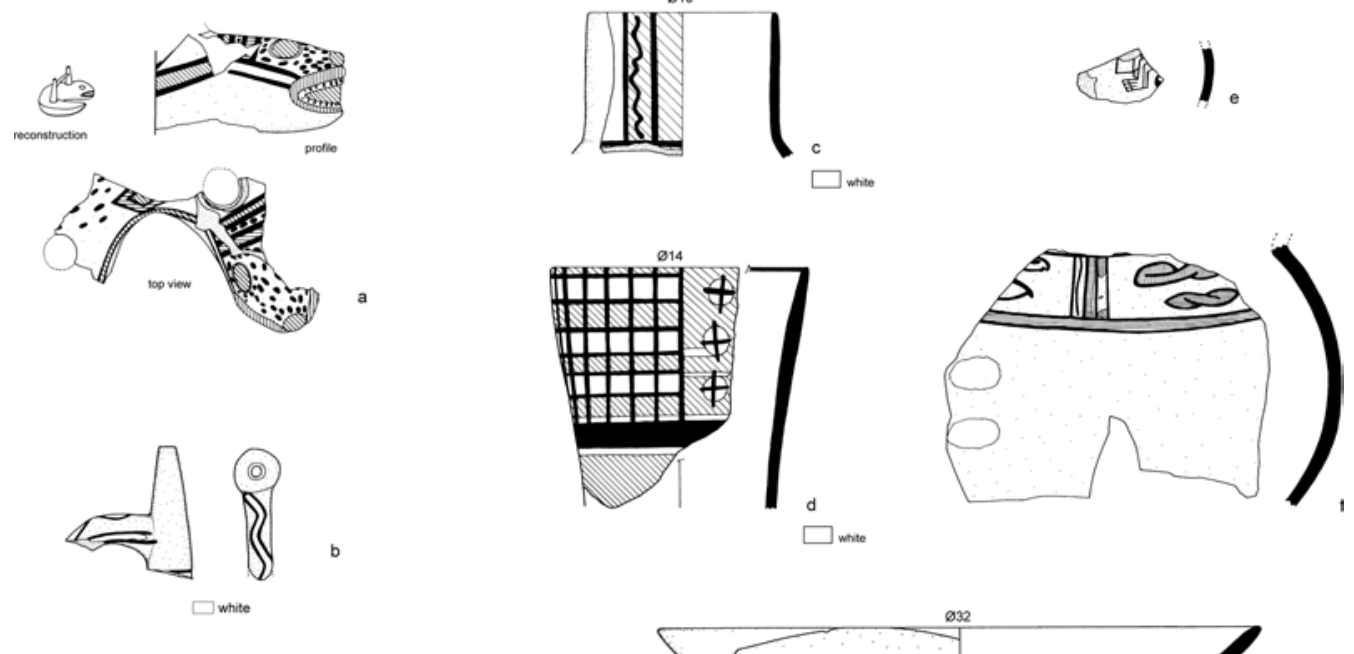

$\square$ white

and

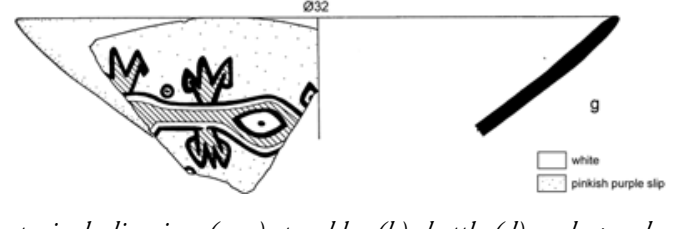

Figure 5. Nieveria style $(b, c)$ and Wari polychrome imports, including jars $(a, c)$, tumbler $(b)$, bottle (d) and open bowls (e-g), found at Chinchawas.

is also considerable evidence for other products imported from the Central Highlands, e.g. obsidian (below). Chinchawasi 2 peoples, however, experienced influences from a number of regional cultures, but subscribed to none of them entirely.

These data contrast with nearby Honcopampa, a contemporary settlement, where D-shaped and patio-group architecture show stronger ties to Wari. According to Isbell (1991), Honcopampa was Wari's regional administrative centre in the Callejón de Huaylas (cf. Tschauner 2003). Notably, Chinchawas neither manifested nor emulated any of these architectural forms. More likely, Chinchawas continued to be an independent settlement within a much larger socio-political system in which Wari grew increasingly paramount. Wari's effect at Chinchawas was felt most dramatically mainly in terms of imported commodities and increased trade, in general.

\section{Warmi phase}

Commerce for imported pottery reached unprecedented levels during the Warmi phase (c. AD 850-950). The sample of imported pottery (352 sherds) is greater than the previous three phases combined. There was also greater diversity in the styles represented.

Warmi phase networks for inter-regional ceramic exchange were largely reconfigured. First, the Callejón de Huaylas sources diminished in importance. Fine pinkware ( 7.7 per cent) decreased, as did Wilkawaín resist (0.3 per cent). Recuay style kaolinite and indeterminate kaolinite categories occurred at 0.9 per cent each, and, most likely, were the result of curation or redeposition in the terrace areas. Notably, there were greater numbers of Cajamarca cursive sherds ( 1.4 per cent) but Cajamarca-related pottery decreased to only 


\section{G.F. Lau}
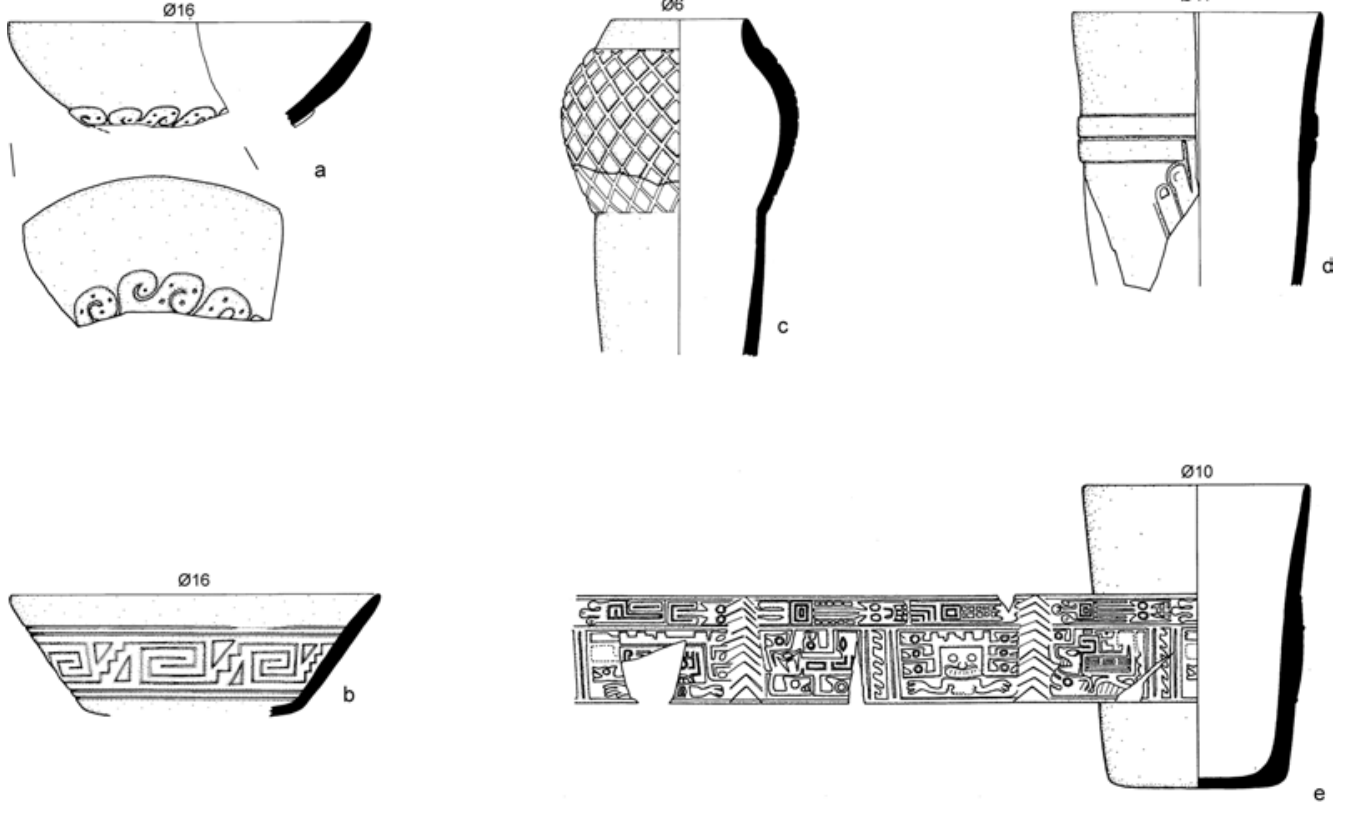

Figure 6. Coastal style press-moulded pottery recovered at Chinchawas, consisting of exterior-decorated open bowls $(a, b)$ and drinking tumblers (c-e).

0.6 per cent, suggesting that local peoples had better access to the more finely made Cajamarca pottery and became less interested in copies.

The presence of Wari-related styles (Figure $5 \mathrm{c}-\mathrm{g}$ ) emphasises the continued cultural importance of the Central Highlands. Wari polychrome, fine orange and fine red burnished, occurred in roughly the same percentages, at 9.7 per cent, 4.8 per cent and 0.9 per cent, respectively. In volume exchanged, however, these import types nearly doubled. Examples of Viñaque style pottery ( 1.1 per cent, $n=4)$ also support the picture of strong Central Highland ties.

A number of other pottery wares altered in popularity during the Warmi phase. Fine grey $(0.3$ per cent $)$ and purple iridescent $(0.9$ per cent $)$ ceramics declined sharply. Face-neck pottery also decreased in importance ( 7.7 per cent), as did Nievería ( 0.6 per cent) from the Central Coast. Polished blackware and modelled polished blackware frequencies rose sharply to approximately 18.4 per cent of the Warmi phase imports. Some of the modelled blackware can be attributed to North Coast styles (lenticular forms, figural imagery) as well as to highland/Central Coast traditions (banded tumblers). Like Viñaque, a black-white-red style (10.2 per cent), associated with Huari Norteño B, represented another ware that appeared for the first time. This pottery was found nearly exclusively in the chullpas of Sector 2, highlighting the importance of coastal Wari period vessels as highland grave offerings.

Coastal style press-moulded ceramics (34 per cent, $n=121$ ) dwarfed all import categories (Figure 6). This pottery probably had its origins in different valleys of the North (Virú and Santa) and North Central Coasts (Supe, probably Huarmey) (Lanning 1967). Together with 
Huari Norteño, press-moulded pottery signals a dramatic shift towards cultural ties with the coast.

Late expressions of Wari influence, therefore, appeared to have had a very profound impact on Chinchawas. As in earlier times, the local leaders acquired foreign pottery for display in public functions and funerary practices. The surging frequencies of coastal imports suggest that the prestige associations of coastal areas became more desirable and there was greater access to these areas, and/or the popularity of these vessels rose. The accumulation of luxury goods indicates that Warmi groups probably held greater competitive economic status in the region.

While imported pottery emphasised coastal ties, it is notable that Warmi peoples preferred a style of local painted secular pottery that bear Central Highland affinities. These ceramics, termed Warmi Ware A, consist of a common redware, typically flat-based open bowls, with simple interior painted designs usually in dark monochrome: parallel bands, bands/meanders, nested arcs, nested geometrics and pendants (Lau 2001: 237-264). In nearly all respects, Warmi Ware A represented a replacement of the earlier local decorated style. Moreover, the change occurred quickly and definitively. There does not appear to have been a transitional phase, with shared elements or hybrid (e.g. Chinchawasi/Warmi) vessels.

Warmi Ware A style pottery occurred quite extensively in local variants across Peru by the end of Middle Horizon Epoch 2 (Anders 1989; Menzel 1964). Their ubiquity, local pastes and local stylistic mixing indicate that they were not imports. Rather, at least in Ancash, they seem to be material correlates for new, Wari-inspired stylistic dispositions in regional ceramic production and everyday residential consumption.

Finally, the excavations did not recover imported ceramics associated with Chakwas groups (after AD 1000) of the Late Intermediate Period. This pattern contrasts with the intensity and diversity of long-distance exchange in the previous three phases. The extensive trade networks developed earlier were, apparently, severed.

\section{Obsidian}

Obsidian was found in limited quantities at Chinchawas. Fifty-six specimens, consisting mainly of small chips and flakes, were recovered. In tool form, obsidian occurred mainly as projectile points. Several whole specimens were recovered, but the majority were broken fragments (Figure 7). The frequency of obsidian peaked sharply during the Chinchawasi 2 occupation $(n=33)$ and decreased in the subsequent Warmi $(n=12)$ phase. Twenty-seven samples from different phases were treated to neutron activation analysis. All showed a chemical signature consistent with the Quispisisa source near Huanca Sancos, Department of Ayacucho, the Wari heartland (Burger \& Glascock 2000). Obsidian access was greatest during the Chinchawasi 2 phase, when long-distance trade and production activities at Chinchawas were thriving. It is argued that Wari expansion enabled greater availability of fine Central Highland obsidian to people in the Callejón de Huaylas.

\section{Makers' marks}

Evidence for makers' marks on plainware ceramics represents another line of evidence marking the intensification of Wari period economic interaction. The excavations at 

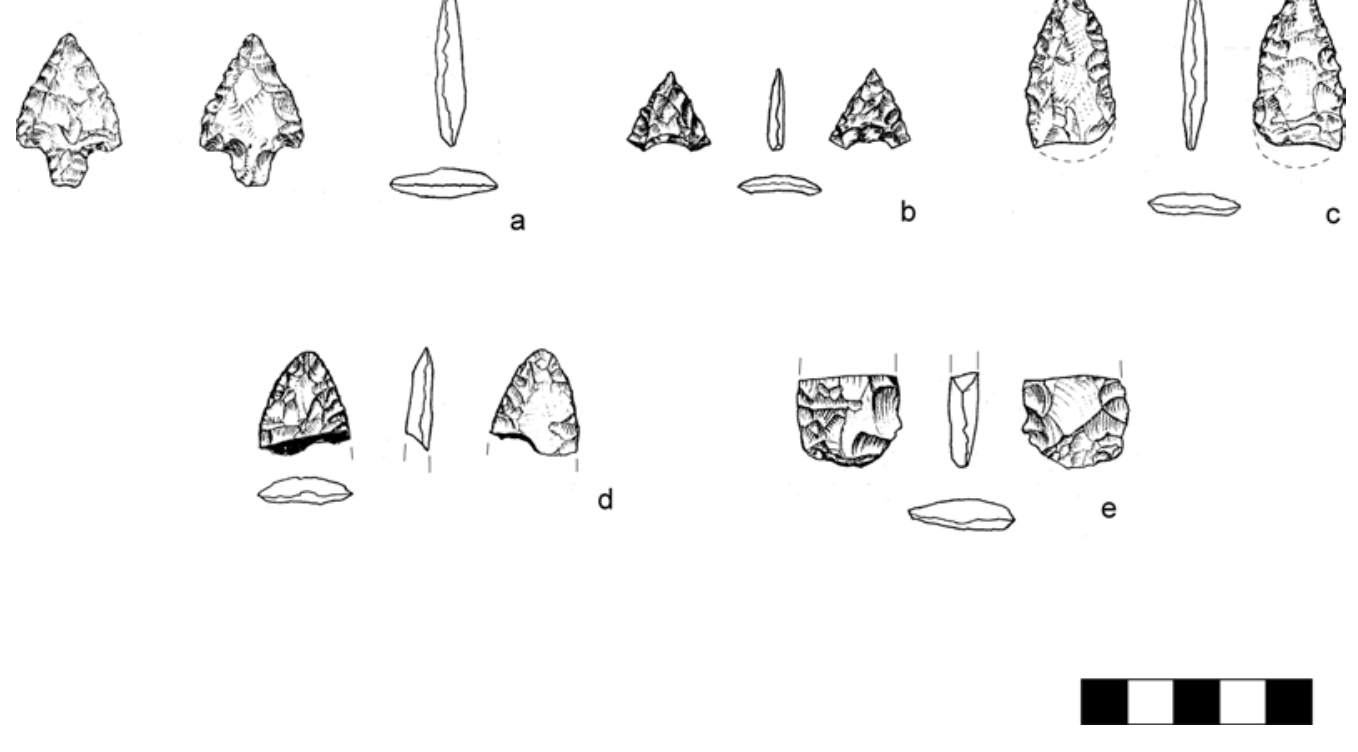

Figure 7. Complete $(a, b)$ and broken $(c-e)$ obsidian projectile points. All the analysed obsidian from Chinchawas derived from the Quispisisa source in the Wari heartland.

Chinchawas recovered twenty-nine examples of strap handles featuring small and relatively basic designs (Figure 8). The marks consist of small incisions, punctations and depressions, none exceeding more than $35 \mathrm{~mm}$ in size. The designs occur mainly on the centre of the handles, but may also feature, sometimes, on one of the handle ends connecting to the vessel body (Figure 9b). In one specimen, the mark appears on both ends of the handle. All the designs were worked when the clay was moist, or leather-hard.

In the Santa Valley, Donnan (1971) recorded forty examples of vessel fragments with very similar marks, associated with Moche culture. Like those of Chinchawas, the marks are small designs rendered through simple plastic decoration and are found on vessels for storage and cooking (Donnan 1971; Shimada 1994). In coastal areas, however, the marks occur primarily on the vessel neck and shoulder (Donnan 1971: 464), while the marks found at Chinchawas are all found on the strap handles. Shimada (1994: 199) mentions a series of appliqué nubbins and animal adornos on shoulders which may have served distinguishing functions similar to the marks. Such elements occur, but very rarely, on plainware jar shoulders at Chinchawas (Figure 9c).

Donnan offered two models to account for the marks, based on ethnographic analogies: manufacture for a market centre, or manufacture by travelling potters. In either case, the marks were used to 'prevent confusing the pots of one potter with those of another during manufacturing', especially when firing vessels by multiple potters (Donnan 1971: 465). Shimada also suggests some form of accounting function (1994: 199, Figure 8.14).

The Chinchawas assemblage is notable for the large number of different marks $(n=21)$ and their archaeological contexts. The earliest secure associations for a marked handle are for the Chinchawasi 2 phase ( $n=7$, six types); the rest pertains to the Warmi phase $(n=17$, thirteen types) and were found in surface/mixed contexts ( $n=5$, five types). The most 
Core-periphery relations in the Recuay hinterlands

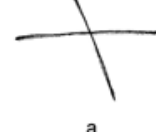

a

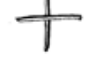

b

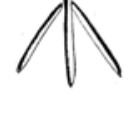

c

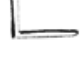

d

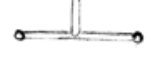

e ofo

f

0

m

g

$\left|\begin{array}{l}0 \\ 0 \\ 0 \\ 0\end{array}\right|$

0
$j$
0

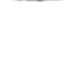

k

I

00

0

$\circ \circ$

$0.0,0.0$

q

$r$
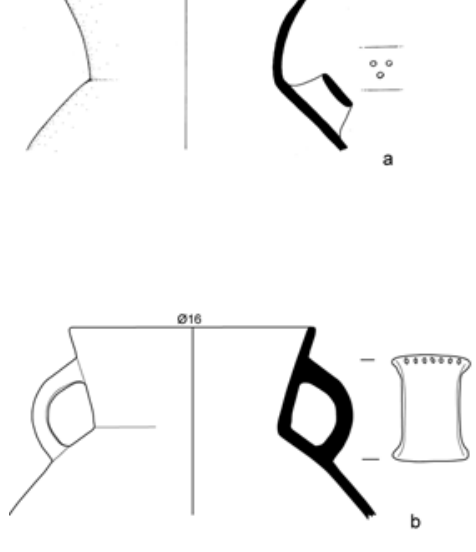

an
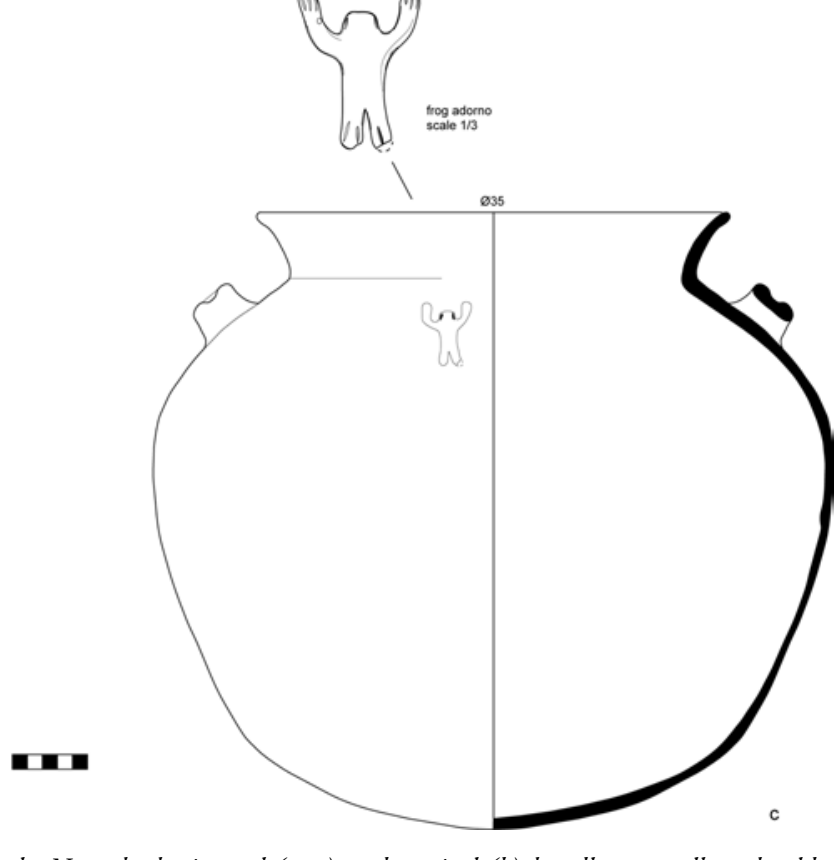

Figure 9. Locations of makers' marks on vessels. Note the horizontal $(a, c)$ and vertical $(b)$ handles, as well as shoulder applique adornos (c), perhaps also used as simple markers. 
popular consists of a small round dimple (e.g. Figure 8m, 8q-r, 9c); this mark occurs eight times in the sample.

The appearance of the marks coincided with the economic prosperity of Chinchawas during the Middle Horizon. The earliest occurrence of the marked handles occurred during the Chinchawasi 2 phase and continued to increase in frequency during the following Warmi phase. Dimple marks were used during the Chinchawasi 2 and Warmi phases, perhaps reflecting continuity in plainware pottery sources.

The different marks suggest variegated sources of manufacture and/or a diverse group of potters. It is unlikely that ceramic manufacture was performed locally. There are no present-day nearby sources of water and wood fuel would have been scarce, as it remains today. The investigations, moreover, did not find evidence for manufacture, such as tools or wasters. More likely, groups began to draw upon a larger range of vessel providers, which is consistent with the general patterns of increased ceramic frequency and diversification of shapes during Chinchawasi phase 2 (Lau 2001: Figure 7.33). Providers were probably from lower down in the Pira valley or the Callejón de Huaylas (e.g. Czwarno 1983; Druc et al. 1998). The widening of exchange networks during the early Middle Horizon at Chinchawas apparently facilitated new forms of and opportunities to acquire plainware ceramics.

\section{Faunal resources}

Faunal remains at Chinchawas were recovered mainly in residential and midden contexts, and are associated with cooking, butchery and consumption activities. A preliminary analysis identified over 13300 individual specimens to family, genus or species level (Lau in press). In general, few species are represented in the sample, which reflects the agro-pastoral specialisation of the village community. Although hunted animals are present in all phases, their contribution to the local diet compared to domestic animals is relatively minor, accounting for approximately $5-15$ per cent of usable meat weight by phase - consisting of deer, viscacha, small rodents and birds.

The faunal assemblage consisted primarily of camelids which represented at least three-quarters of the usable meat weight estimates for each phase: Kayán (75 per cent), Chinchawasi 1 (89 per cent), Chinchawasi 2 (95 per cent) and Warmi (89 per cent) (for comparable figures, see Burger 1985; Miller 1979; Miller \& Gill 1990; Shimada 1982, 1985; Wing 1972, 1980: 159). Camelid use intensified greatly during the early Middle Horizon. The Chinchawasi 2 phase sample consists of at least 96 animals representing over $3300 \mathrm{~kg}$ in usable meat weight - nearly four times the previous occupation's figure. Most of the animals were small-sized camelids, probably domestic alpaca, at a ratio of about 4 to 1 .

In addition to the increasing amount of small-sized camelids available for meat, local peoples probably relied on them for their hair fibre (Gilmore 1950). This is best documented by the large numbers (all phases, $n=266$ ) of spindle whorls and whorl 'blanks' (at different stages of production/breakage) used for processing and spinning camelid hair fibre. Like bone refuse, spindle whorls and blanks occur most frequently during Chinchawasi 2 , and are generally larger in size. 
Overall, the Chinchawasi 2 occupation shows a notable increase in camelid production, as reflected in bone refuse and fibre processing tools. Coeval with early Wari expansion into the Callejón de Huaylas, it is argued that camelid herding intensified to produce critical commodities used in the burgeoning exchange networks fostered by Wari: meat on the hoof, spun yarn and possibly locally made textiles.

\section{Discussion}

Throughout its occupation, Chinchawas was a peripheral community in the affairs of influential regional polities. It was, among other functions, a small node for coast-highland trading networks (Topic \& Topic 1983), which facilitated exchange of agro-pastoral products in return for much-desired foreign goods and materials.

Chinchawas' first occupation, in the Kayán period, is characterised by a fairly insular community that drew culturally from connections with a Recuay to Late Recuay cacicazgo based in Huaraz. The precise nature of the Chinchawas' rapport with Huaraz is unclear, but it was at least partly based on exchange of kaolinite pottery from the Callejón de Huaylas and its attendant cultural/ideological content. Funerary practices and stone sculpture, critical to ancestor veneration, were also shared elements between Chinchawas and Huaraz-area groups. In addition to its religious significance, Huaraz probably served as the gateway centre for prestige ceramics produced in areas with regular access to kaolinite.

By the end of the Chinchawasi 2 phase, in the early ninth century AD, Chinchawas flourished within a wider network associated with Wari's expansion into the North Highlands. This is a period that saw sharp intensification of cultural interaction and economic practices, focused on exchange (e.g. Topic 1991) and camelid products (e.g. Meddens 1989). Small villages, such as Chinchawas, likely entered into exchange relationships with Wari for prestige goods and to enable increased economic interaction.

Cultural transformations were the strongest during the Warmi occupation, with major innovations in local decorated pottery and religious practices (Lau 2002). In addition, imported pottery surged during this period. Unlike earlier occupations when highland styles were the most significant, coastal trade wares took centre stage for Warmi peoples, reflecting stronger cultural interchanges with the Central, North-Central and North Coasts. Notably, camelid production declined considerably, suggesting that previous economic orientations privileging fibre/textile production, associated with earlier Wari exchange interests in the region, did not persist.

Rural perspectives, focused on local agency, therefore provide fuller prehistories of cores and their peripheries. Specifically, the Chinchawas data are consistent with recent models which problematise Wari as a strongly centralised bureaucracy or a conquest state. Local groups at Chinchawas flourished through local strategies to respond to new socio-political conditions. It appears that trade and economic prosperity were vital factors for provincial engagements within larger Andean geopolitical systems. Currently, it cannot be determined if Chinchawas ever contributed labour to the Wari economy.

An important result of the present study is that it charts changing cultural dispositions for long-distance prestige goods, or 'exotica' (Goldstein 2000). Exchange practices favoured North Highland sources initially, but then increasingly emphasised cultural ties to the 


\section{G.F. Lau}

Central Highlands and different coastal regions. Consumption of exotic goods, across this trajectory of taste, was by local peoples who found the cultural content of the objects useful for appropriation in status displays and as funerary equipment.

The frequency and diversity of the exotica, however, are somewhat incongruous with the modest character of Chinchawas. Throughout antiquity, Chinchawas was a small agropastoral village, but the wide spectrum of prestige pottery materialises a rather extensive catchment for exotica and a sustained emphasis or need for their acquisition. The diversity of prestige pottery also suggests that local peoples, especially leaders, were quite aware of and interested in far-flung pottery-producing groups, even if their sources were not contiguous geographically.

The cosmopolitanism at Chinchawas was not a unique phenomenon. Different northern Peruvian groups also benefited from the breaking down of geopolitical and cultural boundaries during the Early Intermediate Period-Middle Horizon transition. For example, investigations in tombs at San Jose de Moro (Castillo Butters 1993) and Cerro Amaru (Topic \& Topic 1992; Topic \& Topic 1984) recovered offerings from various contemporary prestige cultures (e.g. Nievería, Cajamarca, Wari polychromes, coastal Middle Horizon). For Moche groups, the new interest in foreign imagery and external contacts was a sea change in artistic production, which for the better part of a millennium had been characterised by insularity and slow, but coherent stylistic change (Donnan 2003). An analogous process of conservative innovation and limited long-distance exchange followed by radical transformations characterised the Recuay tradition of highland Ancash.

In northern Peru, the vigorous cultural and economic interaction, attributable to Wari interests during the early Middle Horizon (Shady Solís 1988), slowed within a few centuries. At Chinchawas, Wari's decline is felt by the beginning of the Chakwas phase, around AD 9501000. This is expressed most clearly in local decorated ceramics; simple plastic decoration replaced the painting and derivative Wari designs characteristic of the previous Warmi phase. The Chakwas phase is also marked by a drastic decline in the ability to access foreign goods (e.g. ceramics, obsidian and shell), camelid production and overall cultural elaboration. The apparent collapse of the Wari economy, therefore, impacted provincial groups quite structurally. As the mutual relationships between core and periphery are fundamental to the reproduction of the core system, its breakdown creates new, often equally transformative, conditions for its client groups (Chase-Dunn \& Hall 1997).

\section{Conclusions}

The different lines of archaeological evidence have demonstrated changing core-periphery relations at a rural settlement in highland Ancash. Long-distance goods documented regional interaction for prestige goods. Patterns in ceramic consumption and faunal resources provided new insight into intensified economic interactions and rural responses to core expansion.

The findings suggest that studies of social complexity would benefit from additional work in provincial regions where complex political systems meet. Local responses to external influences can be characterised as highly selective and variable, both at the synchronic and diachronic levels. Core developments can promulgate rural complexity, such as in 
economic enterprises and specialisation (e.g. camelid herding, long-distance exchange, stylistic emulation), at the same time that there may be heightened forms of local innovation and cultural expression - e.g. funerary monuments, proliferation of stone sculpture and display (Lau 2002). Under different times and contexts, we should expect that cultural and socio-political relations will alter in any core-periphery arrangement. It is argued that multiple lines of evidence from site-level research are needed to build plausible models of economic interaction by phase. Finally, the research advocates that a rural community perspective has particular utility for understanding the timing and character of coreperiphery interaction in the ancient Andes.

\section{Acknowledgements}

This manuscript evolved out of a paper presented at the 2002 Annual Meeting of the Society for American Archaeology (Denver), for the symposium 'Diversity within Andean Societies and Polities; Reconsidering Peripheries, Cores, Spheres of Influence and Boundedness'. I would like to thank Tom Zoubek and Christine Beaule for inviting me to participate in the session. The fieldwork at Chinchawas was conducted under Resolucíon Directorial Nacional 419-96/INC; special thanks to César Serna Lamas and Wilder León Ascurra (INC-Huaraz) and to Jorge Silva, Luis Jaime Castillo and Lida Casas in the Lima office. I wish to thank the National Science Foundation (SBR-9612574) and the Wenner-Gren Foundation for Anthropological Research (6066) for sponsoring the field research, as well as Yale Albers Fund, John F. Enders fellowship and Sigma Xi GIAR support for specific technical analyses. I would also like to thank Joanne Clarke, Ludovic Coupaye, Helen Southwood, Richard Burger and Jeffrey Quilter for making very helpful comments on shaping this manuscript. Richard Burger enabled the NAA analysis of obsidian samples to be done as part of an ongoing collaboration with Michael Glascock at the University of Missouri Research Reactor. A final word of appreciation goes to Kevin Lane who encouraged me to send this work to Antiquity.

\section{References}

Adams, R. McC. 1965. Land behind Baghdad. Chicago: University of Chicago Press.

Algaze, G. 1993. Expansionary dynamics of some early pristine states. American Anthropologist 95: 304-33.

Anders, M.B. 1989. Wamanga pottery: symbolic resistance and subversion in Middle Horizon Epoch 2 ceramics from the planned Wari site of Azángaro (Ayacucho, Peru), in D.C. Tkaczuk \& B.C. Vivian (ed.). Cultures in conflict: current archaeological perspectives: 7-18. Proceedings of the twentieth annual Chacmool conference, Calgary: Archaeological Association of the University of Calgary.

Bawden, G. 1996. The Moche. Oxford: Blackwell Publishers.

Bennet, W.C. 1944. The North Highlands of Peru: Excavations in the Callejón de Huaylas and at Chavin de Huántar. Anthropological Papers of the American Museum of Natural History 39 (1). New York.

Bermann, M. 1994. Lukurmata: Household archaeology in prehispanic Bolivia. Princeton (NJ): Princeton University Press.
BRAY, T. 2003. Inka pottery as culinary equipment: food, feasting, and gender in imperial state design. Latin American Antiquity 14: 3-28.

Burger, R.L. 1985. Prehistoric stylistic change and cultural development at Huaricoto, Peru. National Geographic Research 1: 505-34.

-1992. Chavin and the origins of Andean civilization. London: Thames and Hudson.

-1993. The Chavín horizon: stylistic chimera or socioeconomic metamorphosis?, in D.S. Rice (ed.). Latin American horizons: 41-82. Washington, D.C.: Dumbarton Oaks.

Burger, R.L. \& M.D. GLasCock. 2000. Locating the Quispisisa obsidian source in the Department of Ayacucho, Peru. Latin American Antiquity 11: 258-68.

Burger, R.L. \& R.M. Matos. 2002. Atalla: a center on the periphery of the Chavín Horizon. Latin American Antiquity 13: 153-77.

Castillo Butters, L.J. 1993. Prácticas funerarias, poder e ideología en la sociedad Moche Tardía. Gaceta Arqueológica Andina 7: 67-73.

Chase-Dunn, C. \& T.D. Hall (ed.). 1991. Core/periphery relations in the precapitalist world. Boulder (CO): Westview Press. 


\section{G.F. Lau}

-1997. Rise and Demise: Comparing World-Systems. Boulder (CO): Westview Press.

Czwarno, R.M. 1983. Ceramic Indications of Cultural Interaction: Evidence from Northern Peru. Unpublished M.A. Thesis, Trent University, Peterborough, Canada.

D'Altroy, T.N. 1992. Provincial power in the Inka empire. Washington, D.C: Smithsonian.

-2002. The Incas. Malden (MA): Blackwell Publishers.

D'Altroy, T.N. \& T.K. Earle. 1985. Staple finance, wealth finance, and storage in the Inka political economy. Current Anthropology 26: 187-206.

Donnan, C.B. 1971. Ancient Peruvian potters' marks and their interpretation through ethnographic analogy. American Antiquity 36: 460-6.

-2003. The long duration and subsequent collapse of Moche borders. Paper presented at Sainsbury Research Unit Americas symposium 'Objects of Contention: Boundaries, Interaction and Appropriation in the Andes', University of East Anglia, Norwich (UK), 9 May 2003.

Druc, I.C. 1998. Ceramic production and distribution in the Chavin sphere of influence (North Central Andes). Oxford: BAR International Series 731.

Druc, I.C., Q. Hugh \& J. Gwyn. 1998. From clay to pots: a petrographical analysis of ceramic production in the Callejón de Huaylas, northcentral Andes, Peru. Journal of Archaeological Science 25: 707-18.

Gilmore, R.M. 1950. Fauna and ethnozoology of South America, in J.H. Steward (ed.). Handbook of South American Indians, vol 6: 345-464. Bureau of American Ethnology Bulletin 143, Washington D.C.

Godelier, M. 1977. Perspectives in Marxist anthropology. Cambridge: CUP.

Goldstein, P. 1993. Tiwanaku temples and state expansion: a Tiwanaku sunken-court temple in Moquegua, Peru. Latin American Antiquity 4: 22-47.

Goldstein, P.S. 2000. Exotic goods and everyday chiefs: long-distance exchange and indigenous sociopolitical development in the South Central Andes. Latin American Antiquity 11: 335-62.

González Carré, E., E. Braygarac Davila, C. Vivanco Pomacanchari, V. Tiesler Blos $\&$ M. Lopez Quispe. 1999. El Templo Mayor en la Ciudad de Wari: Estudios Arqueológicos en Vegachayoq Moqo-Ayacucho. Universidad Nacional de San Cristóbal de Huamanga, Ayacucho.

Grieder, T. 1978. The art and archaeology of Pashash. Austin: University of Texas Press.

Hyslop, J. 1984. The Inka road system. New York: Academic Press.
-1990. Inka settlement planning. Austin: University of Texas Press.

Ibarra, B. (ed.). 2003. Arqueología de la Sierra de Ancash: Propuestas y Perspectivas. Lima: Instituto Cultural Runa.

IsBeLl, W.H. 1977. The rural foundation for urbanism: economic and stylistic interaction between rural and urban communities in eighth-century Peru. Illinois Studies in Anthropology 10. Urbana: University of Illinois Press.

-1988. City and state in Middle Horizon Huari, in R.W. Keatinge (ed.). Peruvian prehistory: 164-89. Cambridge: CUP.

-1991 . Honcopampa: monumental ruins in Peru's North Highlands. Expedition 33: 27-36.

Isbell, W.H. \& G.F. McEwan (eds.). 1991. Huari administrative structure: prehistoric monumental architecture and state government. Washington, D.C.: Dumbarton Oaks.

JANUSEK, J.W. 2002. Out of many, one: style and social boundaries at Tiwanaku. Latin American Antiquity 13: 35-61.

Jennings, J.D. \& N. Craig. 2001. Politywide analysis and imperial political economy: The relationship between valley political complexity and administrative centers in the Wari Empire of the Central Andes. Journal of Anthropological Archaeology 20: 479-502.

Kolata, A.L. (ed.). 2003. Tiwanaku and its hinterland: archaeology and paleoecology of an Andean civilization 2: Urban and rural archaeology. Washington, D.C.: Smithsonian Institution Press.

KuzNar, L.A. 1996. Periphery/core relations in the Inca Empire. Journal of World Systems Research 2: 1-20.

LA Lone, D. 1994. An Andean world-system: production transformations under the Inca Empire, in E.M. Brumfiel (ed.). The Economic Anthropology of the State: 17-42. Lanham, Maryland: University Press of America.

Lanning, E.P. 1967. Peru before the Incas. Englewood Cliffs: Prentice-Hall.

LAU, G.F. 2001. The ancient community of Chinchawas: economy and ceremony in the North Highlands of Peru. Ph.D. Dissertation, Yale University, University Microfilms, Ann Arbor.

-2002. Feasting and ancestor veneration at Chinchawas, North Highlands of Ancash, Peru. Latin American Antiquity 13: 279-304.

-2004. The Recuay culture of Peru's North-Central Highlands: a reevaluation of chronology and its implications. Journal of Field Archaeology 29: 177-202. 
-in press. Animal resources and Recuay cultural transformations at Chinchawas (Ancash, Peru). Andean Past 9.

Lumbreras, L.G. 1960. La cultura de Wari, Ayacucho. Etnología y arqueología 1: 130-227.

-1974. The peoples and cultures of ancient Peru. Washington, D.C: Smithsonian Institution Press.

Malpass, M.A. (ed.). 1993. Provincial Inca: archaeological and ethnohistorical assessment of the impact of the Inca state. Iowa City: University of Iowa Press.

McGuire, R. 1996. The limits of world-systems theory for the study of prehistory, in P.N. Peregrine \& G.M. Feinman (ed.). Pre-Columbian world systems: 51-64. Madison (WI): Prehistory Press.

Meddens, F.M. 1989. Implications of camelid management and textile production for Huari, in F. Meddens, R.M. Czwarno \& A. Morgan (ed.). Nature of Wari: a reappraisal of the Middle Horizon Period in Peru: 146-165. Oxford: BAR International Series 525.

Menzel, D. 1959. The Inca occupation of the south coast of Peru. Southwestern Journal of Anthropology 15: $125-42$

-1964. Style and time in the Middle Horizon. Nawpa Pacha 2: 1-105.

-1977. The archaeology of ancient Peru and the work of Max Uhle. Berkeley: Lowie Museum of Anthropology.

Miller, G.R. 1979. An introduction to the ethnoarchaeology of the Andean camelids. Unpublished Ph.D. Dissertation, University of California, Berkeley.

Miller, G.R. \& A.L. Gill. 1990. Zooarchaeology at Pirincay, a Formative Period site in highland Ecuador. Journal of Field Archaeology 17: 49-68.

Moore, J.D. 1996. Architecture and power in the ancient Andes: the archaeology of public buildings. Cambridge: CUP.

Morris, C. 1986. Storage, supply and redistribution in the economy of the Inka state, in J. Murra, N. Wachtel \& J. Revel (ed.). Anthropological History of Andean Polities: 59-68. Cambridge: CUP.

Morris, C. \& D.E. Thompson. 1985. Huánuco Pampa: an Inca city and its hinterland. London: Thames and Hudson.

Peregrine, P.N. \& G.M. Feinman (eds.). 1996. Pre-Columbian world systems. Madison (WI): Prehistory Press.

Pillsbury, J. (ed.). 2001. Moche art and archaeology in ancient Peru. Studies in the history of art: 63. Washington, D.C: National Gallery of Art.

ReICHeRT, R.X. 1977. The Recuay ceramic style: a reevaluation. Unpublished Ph.D. Dissertation, University of California at Los Angeles, University Microfilms, Ann Arbor.
Rostworowski, M. 1988. Historia del Tahuantinsuyu. Lima: Instituto de Estudios Peruanos.

Rowe, J.H. 1946. Inca culture at the time of the Spanish conquest, in J. Steward (ed.). Handbook of South American Indians 2: The Andean civilizations: 183-330. Washington, D.C.: Bureau of American Ethnology Bulletin 143.

Rowe, J.H. \& D. Menzel (eds.). 1967. Peruvian archaeology: selected readings. Palo Alto: Peek Publications.

Rowlands, M. 1987. Centre and periphery: a review of a concept, in M. Rowlands, M. Larsen \& K. Kristiansen (ed.). Centre and periphery in the ancient world: 1-12. Cambridge: CUP.

Schaedel, R.P. 1952. An analysis of Central Andean stone sculpture. Ph.D. Dissertation, Yale University, University Microfilms, Ann Arbor.

-1993 . Congruence of horizon with polity: Huari and the Middle Horizon, in D.S. Rice (ed.). Latin American Horizons: 225-61. Washington, D.C.: Dumbarton Oaks.

Schreiber, K.J. 1991. Association between roads and polities: evidence for Wari roads in Peru, in C.D. Trombold (ed.). Ancient road networks and settlement hierarchies in the New World: 243-52. Cambridge: CUP.

-1992. Wari imperialism in Middle Horizon Peru. Anthropological Paper 87, Museum of Anthropology, University of Michigan, Ann Arbor.

Schwartz, G.M. \& S.E. Falconer (ed.). 1994. Archaeological views from the countryside: village communities in early complex societies. Washington, D.C: Smithsonian Institution.

SHady Solís, R. 1988. La época Huari como interacción de las sociedades regionales. Revista Andina 6: 67-99.

Shimada, I. 1994. Pampa Grande and the Mochica culture. Austin: University of Texas Press.

Shimada, M. 1982. Zooarchaeology of Huacaloma: behavioral and cultural implications, in K. Terada \& Y. Onuki (ed.). Excavations at Huacaloma in the Cajamarca Valley, Peru: 303-36. Tokyo: University of Tokyo Press.

-1985 . Continuities and changes in patterns of faunal resource utilization: Formative through Cajamarca Periods, in K. Terada \& Y. Onuki (ed.). The Formative Period in the Cajamarca Basin, Peru: excavations at Huacaloma and Layzón, 1982: 289-305. Tokyo: University of Tokyo Press.

Smith, J.W. JR. 1978. The Recuay culture: a reconstruction based on artistic motifs. Ph.D. Dissertation, University of Texas at Austin, University Microfilms, Ann Arbor.

STANish, C. 1997. Nonmarket imperialism in a prehispanic context: the Inca occupation of the Titicaca Basin. Latin American Antiquity 8: 195-216. 


\section{G.F. Lau}

-2001. Regional research on the Inka. Journal of Archaeological Research 9: 213-41.

-2003. Ancient Titicaca: the evolution of complex society in Southern Peru and Northern Bolivia. Berkeley (CA): University of California Press.

Tello, J.C. 1929. Antiguo Peru: primera época. Comisión Organizadora del Segundo Congreso de Turismo, Lima.

Topic, J.R. 2003. From stewards to bureaucrats: architecture and information flow at Chan Chan, Peru. Latin American Antiquity 14: 243-74.

-1983 . Coast-highland relations in northern Peru: some observations on routes, networks, and scales of interaction, in R. Leventhal \& A. Kolata (ed.). Civilization in the ancient Americas: 237-59. Albuquerque: University of New Mexico.

Topic, J.R. \& T.L. Topic. 1992. The rise and decline of Cerro Amaru: an Andean shrine during the Early Intermediate Period and Middle Horizon, in A.S. Goldsmith, S. Garvie, D. Selin, \& J. Smith (ed.). Ancient images, ancient thought: the archaeology of ideology: 167-180. Proceedings of the 23rd annual conference of the Archaeological Association of the University of Calgary, Calgary.

-2000. Hacia la comprensión del fenómeno Huari: una perspectiva norteña. Boletín de Arqueología PUCP 4: 181-217.

TopIC, T.L. 1985. The kaolin ceramic tradition in northern Peru. Paper presented at the fourth annual Northeast conference on Andean Archaeology and Ethnohistory. Albany: SUNY.
-1991. Middle Horizon in Northern Peru, in W.H. Isbell \& G.F. McEwan (ed.). Huari administrative structure: prehistoric monumental architecture and state government: 233-246. Washington, D.C.: Dumbarton Oaks.

Topic, T.L. \& J.R. Topic. 1984. Huamachuco archaeological project: preliminary report of the third season, June-August 1983. Trent University Occasional Papers in Anthropology 1, Peterborough, Ontario.

Tschauner, H. 2003. Honco Pampa: arquitectura de élite del Horizonte Medio del Callejón de Huaylas, in B. Ibarra (ed.). Arqueología de la sierra de Ancash: propuestas y perspectives: 193-220. Lima: Instituto Cultural Runa.

WALLERSTEIN, I. 1974-80. The modern world system I-II. New York: Academic Press.

Wegner, S.A. 1988. Cultura Recuay, Exhibit catalog. Banco Continental and Museo Arqueológico de Ancash (Lima, September-October 1988).

-2003. Identificando el área de dominio Recuay: un extendido inventario cerámico para la identificación de asentamientos Recuay, in B. Ibarra (ed.). Arqueología de la sierra de Ancash: propuestas y perspectives: 121-34. Lima: Instituto Cultural Runa.

WING, E. 1972. Utilization of faunal resources in the Peruvian Andes, in Izumi Seiichi \& Kazuo Terada (ed.). Andes 4: Excavations at Kotosh, Peru: 327-351. Tokyo: University of Tokyo Press.

- 1980. Faunal remains, in T. Lynch (ed.). Guitarrero Cave: Early Man in the Andes: 149-72. New York: Academic Press. 